\title{
Attachment in the student-teacher relationship as a factor of school achievement
}

\begin{abstract}
The purpose of this study was to find out how are the quality of student-teacher interaction and teachers' practices related with school achievement during the primary education. A sample of 366 students attending $4^{\text {th }}$ and $7^{\text {th }}$ grades from Belgrade primary schools participated in the study. We developed a questionnaire measuring seven dimensions of student-teacher attachment (Proximity seeking, Separation protest, Particularity, Safe haven, Secure base, Open communication, and Closeness), and six dimensions of teacher practices (Strict, Leadership, Instructional support, Helping/friendly, Conflict, and Dissatisfaction). The parallel versions of questionnaire, for class teacher in $4^{\text {th }}$ grade, and Math teacher in $7^{\text {th }}$ grade were developed. Based on exploratory factor analysis these dimensions were reduced on fewer number of factors. As educational outcomes, we measured students attitude towards school and learning and school marks. Factors Attachment to teacher, Instructional support, Positive emotional relationship with students, students' Positive attitudes towards school and learning and school marks were taken for structural equation modeling, for each grade separately. Results show that Attachment to teacher affects students Attitudes towards school and learning in both grades and school marks just in $4^{\text {th }}$ grade. In $4^{\text {th }}$ grade, quality of Instructional support and teachers' Positive relationship with students have effect on students' Attachment and directly, on school marks and students' Attitudes towards school and learning, respectively. In $7^{\text {th }}$ grade, quality of teachers' Instructional support has effect on Math marks, while teachers' Positive emotional relation with students affects students' Attachment and Math marks. Results are discussed in the light of the attachment to teacher and the quality of student-teacher socio-emotional interaction as factors that foster teaching and learning.
\end{abstract}

Key words: attachment to teacher, instructional support, school achievement.

Developmental theory and researches provide strong support for the idea that it is the daily interactions that children have with adults and peers that drive learning and development (Bronfenbren-

1 kkrstic@f.bg.ac.rs ner \& Morris, 1998). Typically, educational researches are focused on the cognitive aspects of learning and student-teacher interaction. Increasing number of studies has indicated that children's well-being in the school and the emotional quality of teach- 
er-student interactions are fundamental for school adjustment, learning and achievements (Baker et al., 2003; Catalano et al., 2004; Pekrun, 2005; Sakiz et al., 2012; Wubbels \& Brekelmans, 2005). In this research we study the importance of teacher-child emotional relationship from perspective of the attachment theory.

In spite of different conceptualization, there is a growing convergence in the literature about the importance of emotional and relational constructs such as children's sense of relatedness (Connell, 1990), belongingness (Goodenow, 1993a), school bonding (Catalano et al., 2004), emotional and instructional support (Hamre et al., 2013), educational emotions (Pekrun, 2000; 2005), positive teacherchild relationship (Howes \& Hamilton, 1992; Pianta, 1999) or student-teacher attachment (Bergin \& Bergin, 2009) as contributors to school success. Positive teacher-child relationships provide children with the emotional security necessary to engage fully in learning activities and scaffold the development of key social, behavioral, and self-regulatory competencies needed in the school environment (Pianta, 1999). Despite its importance, there is little research examining the nature or significance of teacher-student relationships during the elementary school period (Baker, 2006).

In this paper we analyze effects of teacherstudents socio-emotional interaction from the perspective of Attachment theory. First, we briefly review the concept of attachment. Then we analyze the relationship between attachment to parents and school achievements. Finally, we discuss a studentteacher attachment relationship. In the methodology, we describe in details present study. Then we present results and discuss their implications for educational practice and research.

\section{Attachment}

Many studies of teacher-child relationship quality have their roots in attachment theory. Attachment is a system of behaviors aimed at establishing and maintaining closeness and contact with an adult figure who is sensible and responsive to the child needs (Bowlby, 1958). Attachment theorists posit that when significant adults provide emotional support and a predictable, consistent, and safe environment, children become more self-reliant and are able to take risks as they explore and learn because they know that an adult will be there to help them (Bowlby, 1969). Studies have shown that securely attached children have better early cognitive development because of activation and maintenance of exploration, curiosity and early learning through new experience (Thompson, 2008; Weinfield et al., 2008). When children feel safe and comfortable, complementary exploratory systems, which encourage them to explore, are activated. Attachment figure will serve as "secure base" from which a child can explore the environment. On the other hand, when children are anxious, distressed or frightened, their attachment systems are activated enforcing them to seek for nearness and closeness with their attachment figures (O'Connor \& McCartney, 2007).

All children will establish attachment relationships with an adult who take care of them, but the quality of attachment varies, depending on the quality of adult-child interaction. According to attachment theorists, four attachment types can be identified: secure, insecure/avoidant, insecure/resistant and insecure/disorganized or controlling (Main \& Cassidy, 1988; Moss \& St-Laurent, 2001).

Attachment relationship influences school adjustment and achievement in two ways: through attachment to parents and through attachment to teachers. 


\section{Attachment to parents and school success}

Large body of studies has shown that secure attachment to parents is linked to cognitive skills and school success (e.g., Van IJzendoorn, Dijkstra, \& Bus, 1995; De Ruiter \& Van IJzendoorn, 1993). Securely attached children at age 7 achieved higher school grades than insecure children throughout primary and secondary school, after controlling for IQ and prior grades (Jacobsen, Edelstein, \& Hofmann, 1994; Jacobsen \& Hofmann, 1997). In another study, it has been found that securely attached children have higher math performance at age 16 than their insecure peers (Teo et al., 1996). Researches indicate that secure children have more advanced cognitive skills, including ability, intelligence, memory, and reasoning than insecure children (Spieker, et al., 2003; Van IJzendoorn, Sagi, \& Lambermon, 1992) and higher scores on communication, cognitive engagement, and mastery motivation (Moss \& St-Laurent, 2001).

In recents studies attachment patterns have been found to predict developmental quotient (Spieker, et al., 2003) and IQ, especially verbal IQ (van Ijzendoorn \& Van Vliet-Visser, 1988; Stievenart et al., 2011; O’Connor \& McCartney, 2007) and academic achievement (Jacobsen \& Hofmann, 1997; Moss \& St-Laurent, 2001).

In sum, attachment studies suggest that secure children tend to have higher verbal ability, math ability, reading comprehension, and overall academic achievement, and exhibit more curiosity than insecurely attached children (Granot \& Mayseless 2001; Pianta \& Harbers, 1996; Weinfield et al.,1999). In high school, insecure students, compared to secure students, were more poorly prepared for exams, did not concentrate as well, feared failure, sought less help from teachers, and gave less priority to studies (Larose et al., 2005).

Based on empirical findings, attachment theorists have developed hypotheses to explain associations between attachment and cognitive skills. Spe- cifically, they assume that secure children engage in more exploration, demonstrate better test-taking skills, receive higher quality maternal instruction and have more supportive social relationships than insecure children (Van IJzendoorn et al., 1995; O’Connor \& McCartney, 2007).

\section{Student-teacher attachment relationship}

Attachment has two functions relevant to classrooms: attachment provides feelings of security, so that children can explore freely; and attachment forms the basis for socializing children (Bergin \& Bergin, 2009). It might be argued that children may use their teacher as a "secure base" for exploring and learning (Bretherton, 1985), for the same sort of emotional security that characterizes the sensitive and responsive parenting (Goosen \& Van Ijzendoorn, 1990; Howes, Phillipsen, \& PeisnerFeinberg, 2000). Similar to parent-child relationships, teacher-child relationships appear to serve a regulatory function with regard to children's social and emotional development (Greenberg, Speltz, \& Deklyen, 1993; Pianta, 1999; Murray \& Greenberg, 2000) and therefore have the potential to exert a positive or negative influence on children's ability to succeed in school.

On the other hand, while they are attachment-like, not all teacher-student relationships should be characterized as attachment, because they have some, but not all, of the characteristics and fulfill some of the functions of an attachment relationship (Bergin \& Bergin, 2009).

Several authors have used concepts from literature on parent-child attachment to define qualities or dimensions of the teacher-child relationship: i.e., secure, avoidant, resistant/ambivalent (Howes \& Hamilton, 1993); optimal, deprived, disengaged, confused, and average (Lynch \& Cicchetti, 1992); and alternatively, closeness, dependency, and conflict/anger (Pianta, Steinberg, \& Rollins, 1995).

Decades of study have shown that the quality of student-teacher relationships, especially en- 
couraging and positive interactions, can have an impact on children's learning, social competences and school adaptation (Howes, Hamilton, \& Matheson, 1994; Howes \& Matheson, 1992; Pianta, Steinberg, \& Rollins, 1995; Egeland \& Hiester, 1995; Howes \& Smith, 1995; Howes, et al., 1990).

Positive teacher-student relationships acts as protective factors for children's social and academic development (Baker, 2006; Pianta et al., 1997; Valiente, et al., 2008) and can be as important as a high quality educational program (Pianta \& LaParo, 2003). Positive or "secure" teacher-student relationships are those perceived by teachers to be high in closeness and low in conflict and dependency. They are marked by respect and caring, with children seeing their teachers as sources of security (Pianta, 1999; Rudasill \& Rimm-Kaufman, 2009). Teacher-student relationship quality predicted academic indicators of school success during the primary school. Researchers found out that girls experienced more closeness and less conflict with their teachers than did boys; and that closeness decrease during the later years of primary school (Baker, 2006).

In elementary school, distinction is made between secure and dependent teacher-student relationships. A secure teacher-student relationship is "characterized by trust, feeling in tune with the student, and perceptions that the student feels safe with the teacher, the student would seek help, and the teacher could console the student" (Pianta \& Nimetz 1991, p. 384). A dependent relationship (or resistant, Howes \& Ritchie, 1999) is characterized by teacher perceptions that the student is "constantly seeking help or reassurance and reacting negatively to separation from the teacher" (Pianta \& Nimetz 1991, p. 385).

Evidence suggests that students with warm and sensitive teacher tend to have greater growth in math and reading ability (Pianta et al. 2008), higher scores on achievement tests, more positive attitudes toward school and more engagement in the classroom (Birch \& Ladd, 1997; Hamre \& Pianta, 2001).
In contrast, children who have conflicted relationships with teachers tend to like school less, experience less self-direction, and show lower levels of cooperation in classroom activities. In sum, empirical studies suggest that secure teacher-student relationships predict greater knowledge, higher test scores, greater academic motivation, than insecure teacher-student relationships (Bergin \& Bergin, 2009).

The antecedents of secure teacher-student relationships are very similar to antecedents of secure parent-child attachment. Students are more likely to develop secure relationships when teachers are involved with, sensitive toward, have frequent positive interactions with children (Howes \& Hamilton 1992a), hold high expectations for students (Davis, 2003), and support students autonomy during classroom assignments (Gurland \& Grolnick, 2003).

Another also important concept in classroom environment research is school bonding or belongingness (Goodenow, 1993b; Sakiz et al., 2012). This concept refers to a sense of belonging at school and commitment to academic goals promoted in the school (Bergin \& Bergin, 2009; Catalano et al., 2004). Students' sense of belonging involves close relationships with peers and teachers, a commitment to succeed in school, participation in extracurricular activities. School bonding is similar to attachment in the way that it makes children feel secure and valued, allowing them to take intellectual and social challenges and explore new ideas. Empirical studies suggest that school bonding is linked to higher academic achievements (Hawkins et al., 2001; Marchant et al., 2001; Battin-Pearson et al., 2000), less delinquent behaviors (O'Donnell et al., 1995; SimonsMorton et al., 1999), less participation in school bullying or violence (Cunningham, 2007) and rare dropout (Hawkins et al., 2001). School bonding and positive attitudes towards school and learning, can also be seen as an important educational outcome, beside cognitive outcomes like knowledge, skills and competencies, especially from a life long learn- 
ing perspective (Gutman \& Schoon, 2013; Rychen \& Salganik, 2003).

\section{Study rational and aims}

In research on emotions in education, what prevail are researches addressing single emotions (like test anxiety) (e.g., Zeidner, 1988), or emotions of teacher or emotions of students, and their function and impact on cognitive processes, teaching and learning (e.g., Ashby, Isen, \& Turken, 1999). More relational approaches are lacking: approaches that will consider emotional relationship between teacher and students as an aspect of psychosocial environment for teaching and learning.

On the other hand, numerous researches are focused on the dynamics of student-teacher instructional/pedagogical interactions and how students learn through that interaction. A new direction in contemporary educational studies are qualitative researches focused on the process of student-teacher interaction and specific acts of students and teachers in that interaction. What these researches lack is perspective on more general emotional relationship between students and teacher. This emotional relationship is relatively stable and enduring factor affecting not only the dynamics of student-teacher relationship and interaction, but also the process of teaching and learning.

The main purpose of this study was to find out how emotional quality of interaction, specifically teacher-student attachment, and characteristics of teachers' practices are related with two important educational outcomes during the primary education: school achievements and students' positive relationship towards school and learning.

\section{Method}

This study was focused on students' interaction with and attachment to teachers at the end of IV and VII grade of a primary school. In the Ser- bian educational system, during the first four years in primary school, children have one class teacher and from V to VIII grade they have different subject teachers. Taking into consideration that Math is one of the key subject in the curriculum, and that previous studies shown that Math class provoke more students' anxiety (Radišić \& Baucal, 2012; Videnović \& Radišić, 2011) this study was focused on students' interaction with class teacher in IV grade and with Math teacher in VII grade.

\section{Sample}

The questionnaire was administered to a sample of 366 students from five Belgrade primary schools.

Table 1. Number of students according to gender and grade

\begin{tabular}{|l|r|r|r|}
\hline \multirow{2}{*}{ Gender } & \multicolumn{3}{|c|}{ Grade } \\
\cline { 2 - 4 } & \multicolumn{1}{|c|}{$4^{\text {th }}$} & $7^{\text {th }}$ & \multicolumn{1}{|c|}{ Total } \\
\hline Female & 95 & 91 & 186 \\
\hline Male & 92 & 88 & 180 \\
\hline Total & 187 & 179 & 366 \\
\hline
\end{tabular}

\section{Instrument}

There are several instruments assessing different aspects of teacher-student social-emotional relationship and interaction in the classroom. Based on the literature review, for the purpose of this research, we developed a self-reporting questionnaire designed to assess students' perception of teacher behavior in the classroom and of quality of teachers' interaction with their students. Items were adapted from several related scales:

1) The Questionnaire on Teacher Interaction (QTI) (Wubbels \& Brekelmans, 1998; Wubbels \& Levy, 1993; Lourdusamy \& Swe Khine, 2001).

2) The Classroom Assessment Scoring System (CLASS; Pianta, LaParo \& Hamre, 2008)

3) The Student Teacher Relationship Scale (STRS; Pianta \& Nimetz, 1991) 
4) The Components of Attachment Questionnaire (CAQ; Parish, 2000; Parish \& Eagle, 2003)

This new questionnaire encompasses following dimensions:

1) The Attachment to teacher scale is modified the Components of Attachment Questionnaire (Parish, 2000) to measures the degree to which a student perceives her/his teacher as an attachment figure. We used five dimensions of the CAQ:

1.1) Proximity seeking (4 items) measures student's need to be near and close to the teacher (e.g. Sometimes I miss my teacher when she is not around).

1.2) Particularity (2 items) measures degree to which a student perceives his/her teacher as a unique, special and irreplaceable figure (e.g. My teacher is more important to me than most other people are).

1.3) Separation protest (3 items) measures degree to which student feels anxious or distress upon separation from teacher as attachment figure (e.g. I feel anxious when our teacher is away).

1.4) Safe haven (7 items) measures degree to which student perceives his/her teacher as a figure to whom she/he can return for comfort and safety when upset in the school (e.g. The teacher is available when I need her).

1.5) Secure base (4 items) measures degree to which student perceives his/her teacher as a secure base for exploration in the school (e.g. My teacher helps me to explore new ideas).

Beside these, two dimensions complementary to attachment were added:

1.6) The Closeness -(4 items, from STRS) measures degree to which a student experiences affection, warmth and open communication with a teacher (e.g. I openly share my feelings and experiences with the teacher).

1.7) The Open communication (5 items) developed for this research to measure de- gree to which student perceive that his/her communication with the teacher is open and trusty, that teacher is available and shows understanding (e.g. When I talk to a teacher, I see that she carefully listens and understands me).

As antecedents of secure teacher-student relationship, several characteristics of teachers' practices were measured:

1) The Leadership (QTI) measures degree to which a student perceives his/her teacher as a person who notices what is happening, leads, organizes, sets tasks, structures the classroom situation, explains, holds the attention (e.g. This teacher knows everything that goes on in the classroom).

2) The Instructional Support (10 items; CLASS, TIMSS, PISA) measures degree to which student perceives pedagogical support that teacher provides to them and perceives teacher's feedback as focused on expanding learning and understanding ( e.g. When I answer in the class, teacher explains what was good and what was wrong).

3) The Strict (3 items; QTI) describes teacher who is demanding, who checks, judges, maintains silence, is strict and sets rules and norms (e.g. The teacher is severe when marking papers).

4) The Helping and Friendly (QTI) describes teacher who assists, behaves in a friendly or considerate manner, is able to make a joke (e.g. The teacher helps us with our work).

5) The Conflict (5 items; STRS) measures degree to which a student perceives her or his relationship with a teacher as a negative and conflictual (e.g. Teacher and I always seem to be struggling with each other).

6) The Dissatisfied (QTI) describes teacher who wait for silence, considers pros and cons, keeps quite, shows dissatisfaction, looks glum, questions, criticizes (e.g. The teacher thinks that we don't know anything). 
The parallel versions of the questionnaire, for class teacher and math teacher were made.

Younger students responded on a threepoint Lickert scale to indicate agreement with each statement (Incorrect, Don't know, and Correct) while older student responded on the five-point Lickert scale (from Totally incorrect to Totally correct).

As a measure of students' achievements, two educational outcomes were measured:

1) The school marks: Because students in $4^{\text {th }}$ grade get all marks from one class teacher, in order to obtain a greater variability of marks, a composite measure was made based on their marks in Math, Serbian language and final mark at the end of the previous school year. For students in $7^{\text {th }}$ grade only Math mark was used.

2) The positive attitude towards school and learning (Popović Ćitić, 2012): this subscale encompasses 7 items that measure: Students' dedication to school and school obligations (I try to achieve as better grades in school); School bonding ( I'm happy to spend time in school); Participation in school activities (I participate in school sections, additional classes or other extracurricular activities in school); Respect of the school norms ( $I$ respect the school rules); Positive attitudes towards learning (Things I learn in school are important and useful).

Data on reliability of all subscales are shown in Table 2. As we can see, except two, the rest of the subscales have moderate to high reliability. Due to the low reliability of subscales Strict and Leadership, they were excluded from further analysis.
Table 2. Reliability of subscales for $4^{\text {th }}$ and $7^{\text {th }}$ grade sample

\begin{tabular}{|l|c|c|}
\hline \multirow{2}{*}{\multicolumn{1}{|c|}{}} & \multicolumn{2}{|c|}{ Cronbach's Alpha } \\
\cline { 2 - 3 } & $4^{\text {th }}$ grade & $7^{\text {th }}$ grade \\
\hline Attachment to teacher & .919 & .930 \\
\hline $\begin{array}{l}\text { Positive attitudes towards school and } \\
\text { learning }\end{array}$ & .650 & .723 \\
\hline Strict & .324 & .318 \\
\hline Leadership & .361 & .543 \\
\hline Instructional support & .601 & .719 \\
\hline $\begin{array}{l}\text { Positive emotional relationship with } \\
\text { students }\end{array}$ & .548 & .555 \\
\hline
\end{tabular}

\section{Procedure}

After the students' agreement to participate in this research was obtained, the questionnaire was administered to all students during the class. Completion of questionnaire lasted less than 45 minutes in both $4^{\text {th }}$ and $7^{\text {th }}$ grades.

\section{Results}

The current study focused on the relations among dimensions of students' attachment to teacher, and students' perception of teachers' behaviors and interaction on one side, and on the other side, students' school achievements, measured through school marks and students' positive attitude towards school and learning. Separate analyses were done for student from $4^{\text {th }}$ and $7^{\text {th }}$ grade. Considering a large number of dimensions, in order to determine relationship between these dimensions, several EFA were done.

\section{Structure of relationship between attachment dimensions}

The EFA for seven dimensions of attachment to teacher has shown that these dimensions together make one factor in both age groups, as it was hypothesized based on conceptual meaning of these dimensions. Using principal component analysis one factor with eigenvalue larger than one was ex- 
tracted explaining $64 \%$ of variance in $4^{\text {th }}$ grade (eigenvalue $=4.47$ ) and $65 \%$ of variance in $7^{\text {th }}$ grade (eigenvalue $=4.56$ ). This factor is called Attachment to teacher and its structure is shown in Table 3.

Table 3. Component matrix of the first factor of seven attachment dimensions

\begin{tabular}{|l|r|r|}
\hline Dimension & $\begin{array}{c}\text { Component 1 } \\
\mathbf{4}^{\text {th }}\end{array}$ grade & $\begin{array}{c}\text { Component 1 } \\
\mathbf{7}^{\text {th }} \\
\text { grade }\end{array}$ \\
\hline Safe haven & .870 & .897 \\
\hline Secure base & .857 & .866 \\
\hline Proximity seeking & .826 & .807 \\
\hline Closeness & .804 & .870 \\
\hline Open communication & .793 & .795 \\
\hline Particularity & .720 & .671 \\
\hline Separation protest & .711 & .716 \\
\hline
\end{tabular}

Students who have high scores on this factor, perceive their teacher as a figure which can comfort them, to whom they can return if they are distressed in school, and also who is secure base for exploration and learning in classroom environment. They seek for nearness and closeness with the teacher, have open communication with her/him, and are dissatisfied when teacher is not around.

\section{Structure of relationship between dimensions of teachers' practices}

Second analysis on the dimensions of students' perception of teachers' practices, has shown that dimension Instructional support stands as an independent variable, while dimensions Helping and friendly, Dissatisfied and Conflict make one factor, which explains $68 \%$ of variance in $4^{\text {th }}$ grade (eigenvalue $=2.028$ ) and $72 \%$ of variance in $7^{\text {th }}$ grade (eigenvalue $=2.159$ ).

Based on the meaning of these dimensions, this factor is called Positive emotional relationship with students (Table 4).

The Positive emotional relationship factor describes students' perception of their teacher as helpful and friendly, with whom they have rare conflicts and who exhibits satisfaction with his/her relationship with students.

Table 4. Component matrix of factor Positive emotional relationship with students

\begin{tabular}{|c|c|c|}
\hline Dimensions & $\begin{array}{c}\text { Component } 1 \\
4^{\text {th }} \text { grade }\end{array}$ & $\begin{array}{c}\text { Component } 1 \\
7^{\text {th }} \text { grade }\end{array}$ \\
\hline Conflict & -.864 & -.873 \\
\hline Dissatisfied & -.814 & -.841 \\
\hline $\begin{array}{l}\text { Helping and } \\
\text { Friendly }\end{array}$ & .786 & .830 \\
\hline
\end{tabular}

\section{Relationship between attachment \\ to teacher, school achievements and teachers' practices}

The current study focused on the relations among primary school students' Attachment to teacher, students' perceptions of teachers' behaviors and interactions assessed by Instructional support and Positive emotional relationship with students' $\mathrm{di}$ mensions, and students school marks and Positive attitude towards school and learning. The relations among these variables were tested using structural equation modeling (SEM) (Byrne, 2001).

In the theoretical model we hypothesized that students' Attachment to teacher will influence his/her school marks and Positive attitude towards school and learning. Besides that, we assumed that students' perception of teachers' practices assessed through dimensions Instructional support, and Positive emotional relationship with student will affect students' attachment to teacher and, independently students marks and Positive attitude towards school and learning. This model is shown in Figure 1. 


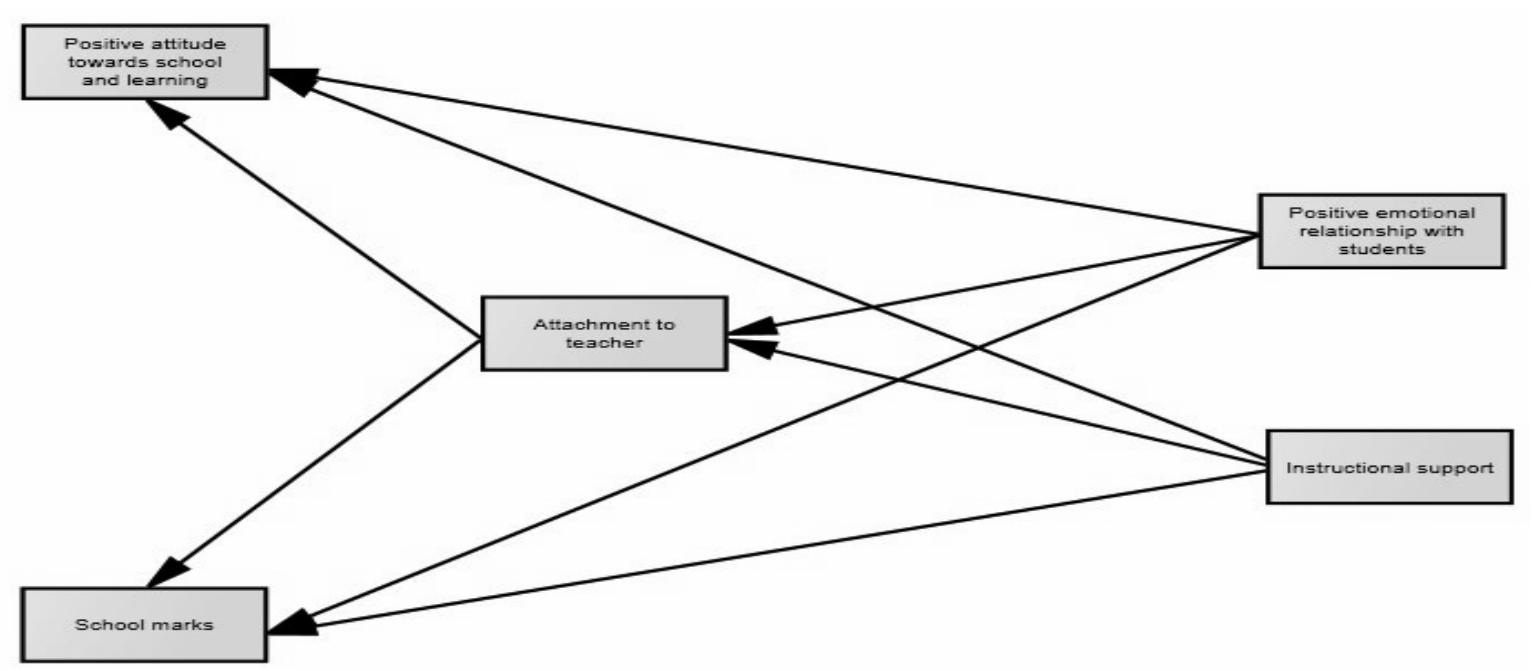

Figure 1: Theoretical model of assumed relationships between dimensions

The SEM model ( $4^{\text {th }}$ grade)

SEM analysis shows that this theoretical model fits to empirically obtained data $\left(\chi^{2}(3)=.991\right.$, $\mathrm{p}=.803, \chi^{2} / \mathrm{df}=.330, \mathrm{RMR}=.026, \mathrm{GFI}=.998, \mathrm{RM}-$ $\mathrm{SEA}=.000$ ) allowing us to analyze individual relations within the model.

As it can be seen from the Figure 2 not all theoretically assumed relationships between variables are statistically significant. Dimension Instructional support does not have direct effect on positive attitudes towards school; and dimension Positive emotional relationship has no effect on school marks. Model in Figure 2 depicts just statistically significant relationships between variables (parameters are shown in Table 10).

As we can see, Attachment to teacher in $4^{\text {th }}$ grade, has a direct effect on both measures: students' school marks and Positive attitudes towards school and learning. Students in the $4^{\text {th }}$ grade who have warm, close and secure relationship with their teacher have better school achievements as well as they perceive school as something useful and interesting, and themselves as more dedicated to school. On the other hand, students will have more positive and secure relationships with a teacher if a teacher has more positive emotional relationship towards

Table 10. Standardized regression coefficients of the model for $4^{\text {th }}$ grade

\begin{tabular}{|c|c|c|c|c|}
\hline \multicolumn{2}{|r|}{ Relation } & $\begin{array}{c}\text { Standardized } \\
\text { regression coefficients }\end{array}$ & Critical ratio & $\mathrm{p}$ \\
\hline Attachment to teacher & $\begin{array}{l}\text { Positive attitudes towards } \\
\text { school and learning }\end{array}$ & .111 & 4.810 & .000 \\
\hline Attachment to teacher & ---->> School marks & .619 & 4.126 & .000 \\
\hline Instructional support & ----> Attachment to teacher & .297 & 4.692 & .000 \\
\hline Instructional support & ---->> School marks & .404 & 2.691 & .007 \\
\hline $\begin{array}{l}\text { Positive emotional } \\
\text { relationship }\end{array}$ & ----> Attachment to teacher & .420 & 6.646 & .000 \\
\hline $\begin{array}{l}\text { Positive emotional } \\
\text { relationship }\end{array}$ & $\begin{array}{l}\text { Positive attitudes towards } \\
\text { school and learning }\end{array}$ & .122 & 5.315 & .000 \\
\hline
\end{tabular}




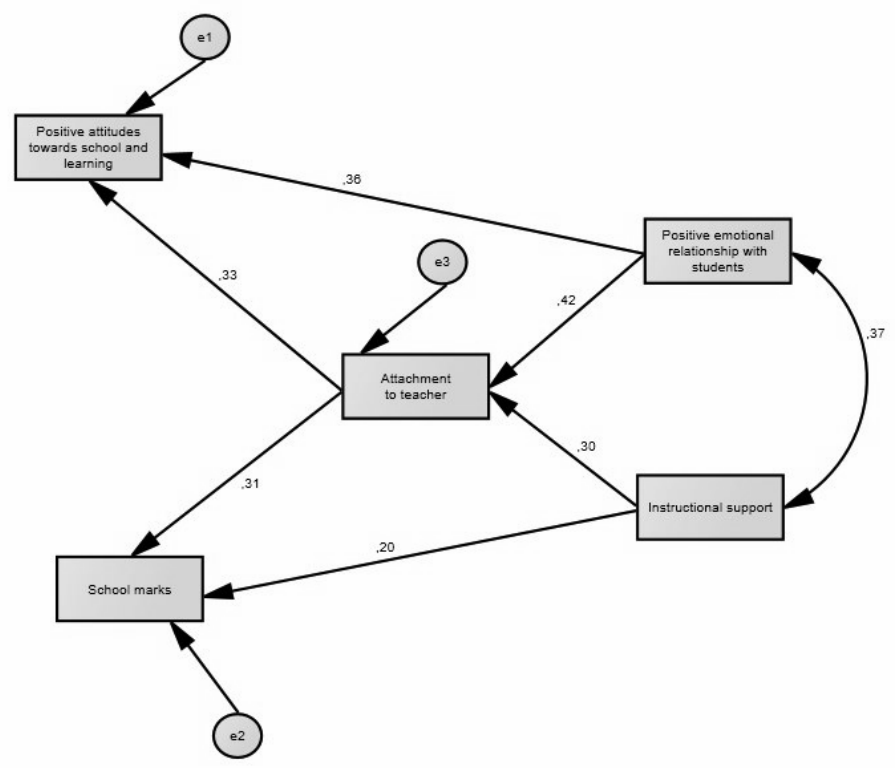

Figure 2: Parameters of the model of relations between students attachment to teacher, dimensions of teacher behavior and students school achievements in $4^{\text {th }}$ grade (standardized regression coefficients)

students and offers them more instructional support.

Teachers' positive emotional relationship towards students and a quality of instructional support have also a direct influence on students' positive attitudes towards school and school marks, respectively, beside their indirect effect through the students' attachment to teacher. If a teacher has more positive emotional relationships with students, students will have more positive attitudes towards school and learning. But this positive emotional relationship will have no influence on students' marks. If teacher gives more instructional support and higher quality of feedback to students, they will have better school marks, but it will not influence their attitudes towards school.

Model in Figure 2 also shows that dimensions of teacher behavior are correlated. Dimension Positive emotional relationship is correlated with Instructional support. Teachers who have more positive emotional relationships with students will give more instructional support.

\section{The SEM model ( $7^{\text {th }}$ grade)}

The same theoretical model of relations between variables was applied on data from $7^{\text {th }}$ grade students. This theoretical model fits to empirically obtained data on older sample, which means that this model can reproduce matrix of covariances of tasted variables $\left(\chi^{2}(6)=6.372, p=.383, \chi^{2} / \mathrm{df}=\right.$ $1.062, \mathrm{RMR}=.050, \mathrm{GFI}=.986, \mathrm{RMSEA}=.019)$.

Model obtained for $7^{\text {th }}$ grade sample data also has theoretically assumed relationships between variables that are not statistically significant. Attachment to Math teacher has no effect on Math marks, Instructional support does not affect neither Attachment to teacher and Positive attitudes towards school. Dimension Positive emotional relationship with students have no effect on Positive attitudes towards school.

Model in Figure 3 depicts just statistically significant relationships between variables. Values of statistically significant parameters of the model for $7^{\text {th }}$ grade are shown in Table 11 . 
Table 11: Standardized regression coefficients of the model for $7^{\text {th }}$ grade

\begin{tabular}{|c|c|c|c|c|c|}
\hline \multicolumn{3}{|c|}{ Relation } & \multirow{2}{*}{$\begin{array}{c}\text { Standardized } \\
\text { regression } \\
\text { coefficients }\end{array}$} & \multirow{2}{*}{$\begin{array}{c}\text { Critical ratio } \\
6.270\end{array}$} & \multirow{2}{*}{$\begin{array}{c}\mathrm{p} \\
.000\end{array}$} \\
\hline Attachment to teacher & $---->$ & $\begin{array}{l}\text { Positive attitudes towards } \\
\text { school and learning }\end{array}$ & & & \\
\hline Instructional support & $-\cdots>$ & Math marks & .303 & 4.211 & .000 \\
\hline $\begin{array}{l}\text { Positive emotional } \\
\text { relationship }\end{array}$ & $---->$ & Math marks & .370 & 5.134 & .000 \\
\hline $\begin{array}{l}\text { Positive emotional } \\
\text { relationship }\end{array}$ & $---->$ & Attachment to teacher & .554 & 8.870 & .000 \\
\hline
\end{tabular}

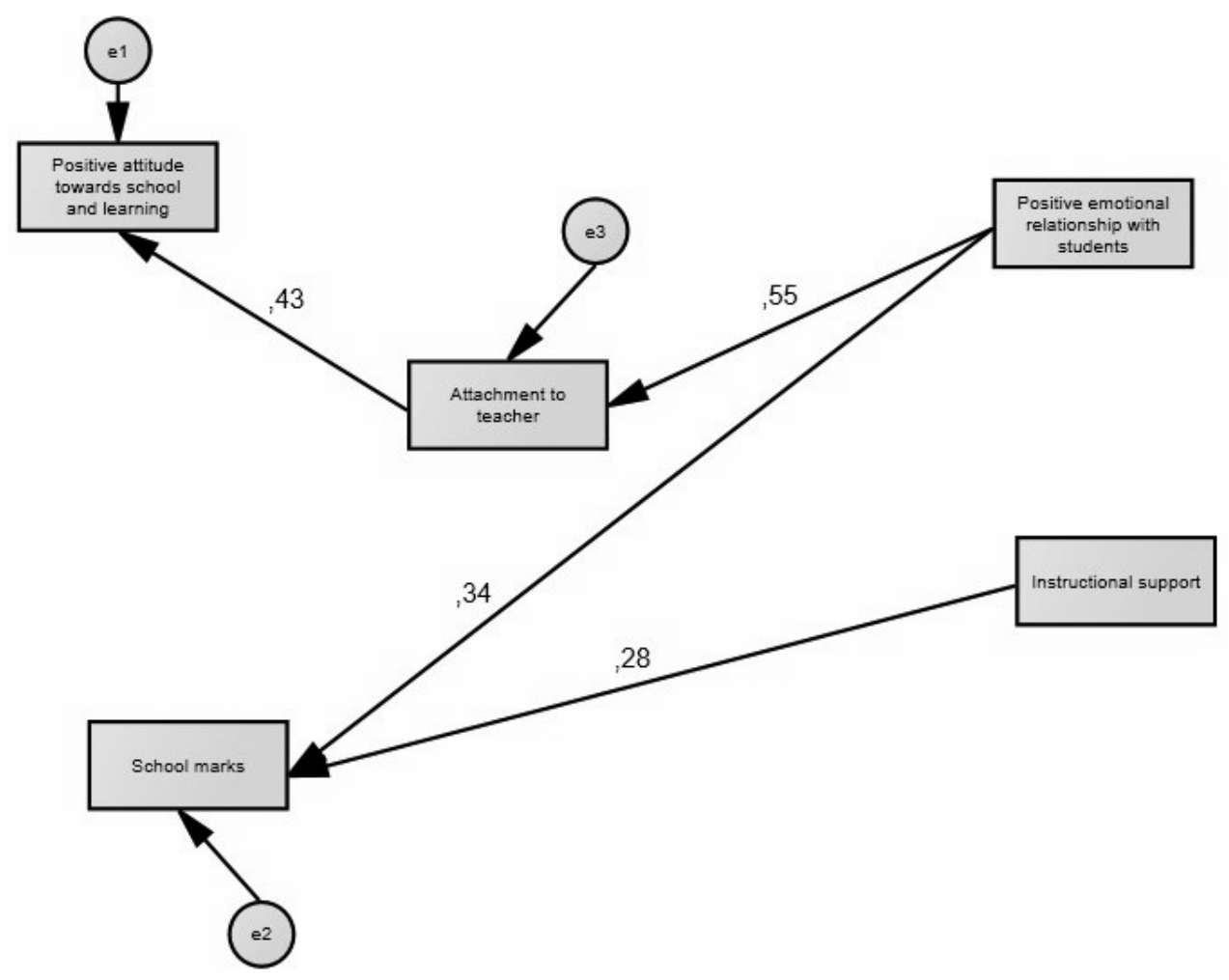

Figure 3: Parameters of the model of relations between students attachment to teacher, dimensions of teacher behavior and students school achievements in $7^{\text {th }}$ grade (standardized regression coefficients) 
Attachment to Math teacher in $7^{\text {th }}$ grade has a direct effect only on a students' Positive attitudes towards school and learning, but not on students' Math marks. An emotional relationship with a teacher will have effect on general emotional attitude towards school, but will not affect school achievements.

On the other hand, students will develop attachment relationship with Math teacher if they perceive him/her as helpful, friendly and satisfied.

On this age level, Math marks are under the influence of two dimensions of teachers' behavior: teachers' Positive emotional relationship with students and quality of Instructional support. Students in $7^{\text {th }}$ grade will have better Math marks if a teacher is giving more or better instructional support, and she/he is helping and friendly, satisfied and has rare conflicts with students.

Model in Figure 3 shows that there is no relations among dimensions of teacher behavior. According to seventh grade students, teachers' positive emotional relationship with students have no relation with the quality of teachers' instructional support.

\section{Interpretation and discussion}

The goal of this study was to analyze direct and indirect relations between teachers' behaviors and practices, student-teacher attachment relationship and educational outcomes. The findings extend our understanding of relationships between the student-teacher attachment and students school marks and attitudes towards school and learning in primary school. Results show that attachment to class teacher in $4^{\text {th }}$ grade has influence on both school marks and attitudes towards school, while, in $7^{\text {th }}$ grade, attachment to Math teacher has influence just on students' attitudes towards school and learning and not on the Math marks.

The findings about effect of the attachment to teacher on school marks in $4^{\text {th }}$ grade suggest that, in warm, supportive, "secure" environment students achieve better school results. This finding is in concordance with findings from other researches indicating that secure teacher-student relation support learning and exploration in school, as the relation of the same quality with parents does (Hamre et al., 2013; Krstic, 2012; Bergin \& Bergin, 2009; Pianta et al., 2008). If students perceive their teacher as a warm, sensitive, responsive, supporting, if they feel secure and valued, that can encourage them to take on intellectual and social challenges, to explore new ideas and to learn.

The findings also suggest that there are some age differences in effect of student-teacher attachment. Math marks in $7^{\text {th }}$ grade are not under the influence of students' attachment with Math teacher. Students will have better Math marks if Math teacher has just positive emotional relation with them. So, in $7^{\text {th }}$ grade, math teacher does not have to be an attachment figure for students, to comfort and to be a secure base for them, but just to be helpful and friendly, satisfied and non-conflictual. This finding is in concordance with results of earlier studies suggesting that association between the teacher-student relationship and cognitive outcomes is not as consistent as association between that relationship and emotional outcomes (motivation, positive attitudes) (Wubbels \& Brekelmans, 2005). However, this finding can also reflect key developmental changes typical for the transition from the middle childhood to the adolescence. For first four years of primary school, students have one class teacher for all subjects. In the same time, they still have a need for a stable, warm and sensitive adult figure. A class teacher can serve as a "parent" in the school and if a class teacher is warm and sensitive, student will develop attachment relationship. From $5^{\text {th }}$ grade, students have different teachers for every subject. Subject teacher spend less time with particular students and develop different relation with them, less warm and sensitive. Besides that, students in $7^{\text {th }}$ grade, being adolescents, have a less need for attachment fig- 
ure than younger students. In that age they seek for peer attachments. In their relation with teachers, they make more differentiation between emotional relations and pedagogical support from teachers. So, the quality of instructional support and quality of feedback from teacher affect their marks, but emotional relation with teachers affects only general attitudes towards school.

Our findings show that the positive and secure relation with teacher, affects not only school marks, but also affects development of positive attitudes towards school and learning. Students' positive attitudes towards school and learning, as an important educational outcome, is under the influence of students' attachment to teacher on both ages. On younger age, these positive attitudes are also affected by teachers' positive emotional relationship with students, while on older age, there is no such effect. If younger students have positive and secure relationship with their teacher, if they feel safe to explore and learn, that will affect their overall perception and experience with a school. This finding supports Cornelius-White (2007) claim, that most students who dislike school do so primarily because they dislike their teacher. This is also important because, several studies have linked school bonding to academic achievement (Hawkins, et al., 2001; Marchant et al., 2001; Battin-Pearson et al., 2000). Children who feel a sense of attachment to school and who develop a commitment to succeed in school are more successful academically.

As the antecedents of student-teacher attachment, this study has highlight positive emotional relationship with students on both ages. On younger age, instructional support also affect students' attachment with teacher, while in $7^{\text {th }}$ grade, quality of teachers' instructional support has no influence on students' emotional relation with a teacher. Earlier studies have pointed out teacher characteristics such as caring, interest in, respectful encouraging, fair as associated with several positive educational outcomes: school achievement and attitudes (Bak- er et al., 2003), increased self-esteem (Reddy et al., 2003); academic achievement (Goodenow, 1993a); academic effort (Wentzel, 1997); classroom engagement (Tucker et al., 2002); school motivation (Stipek et al., 1998). Several studies reported that students prefer teachers who care and hold high academic expectations (Muller, Katz, \& Dance, 1999; Murdock, 1999; Davis, 2003; Sakiz et al., 2012). These teacher characteristics may improve the psychological climate of the classroom and increase the feeling of safety, which encourage students' classroom engagement and learning. In a meta-analysis on 119 studies, Cornelius-White (2007) found a moderate correlation across several person-centered teacher variables (such as empathy, warmth, encouraging) and student achievement and attitudes. Another metaanalysis of classroom climate, found that a common attributes that optimize student learning are goal directedness, positive interpersonal relations, and social support (Hattie, 2009). So, we can conclude that student-teacher attachment will develop when a teacher has a positive emotional relationship with students: when he/she is helpful, friendly, satisfied and non-conflictual.

One more important characteristic of teachers' practices that influence students' achievements and quality of relationship with the teacher is instructional support. A quality of teachers' instructional support-pedagogical support and quality of teachers' feedback, has direct influence on both school marks in $4^{\text {th }}$ grade and Math marks in $7^{\text {th }}$ grade. Hamre and her colleagues also found that teachers' instructional support predict students' academic functioning and engagement in classroom activities (Hamre et al., 2013). In $4^{\text {th }}$ grade, instructional support has also important effect on studentteacher attachment.

At the end, based on these findings we can conclude that in the $4^{\text {th }}$ grade secure student-teacher attachment affects both measured educational outcomes, school marks and positive attitudes towards school and learning. Students will develop secure at- 
tachment to teacher if a teacher has a positive emotional relationship with students and gives them a high-quality instructional support. In $7^{\text {th }}$ grade, students do not need an attachment figure to have good Math marks. At this level, attachment to teacher will affect students' positive attitudes towards school and learning. Math marks in $7^{\text {th }}$ grade depend on teachers' instructional support and positive emotional relationship with students.

The positive relations between attachment to teacher and students educational outcomes found in this study provide evidence for the importance of developing positive emotional relationship in a classroom and creating warm, sensitive and supporting learning environment in schools. This study suggests that more attention should be paid on emotional relationships between students and teachers. In a context of positive emotional relationship with the teacher, a large number of students will develop positive attitudes towards school and learning, and in lower grades, they will achieve better school marks. This research also indicates that emotional interaction and attachment are important and fruitful domain for educational researches. Teachers' relationship with students and their practices can be described and measured through large number of different dimensions, in this research we cover just few of them. Also, as our study reveal, there are some age differences that should be taken into consideration. Our understanding of student-teacher interaction and relations could be extended with a qualitative researches which would reveal mechanisms in the base of those relations.

\section{References}

- Ashby, F. G., Isen, A. M., \& Turken, A. U. (1999). A neuropsychological theory of positive affect and its influence on cognition. Psychological Review, 106, 529-550.

- Baker, J.A. (2006). Contributions of teacher-child relationships to positive school adjustment during elementary school. Journal of School Psychology (44); 211-229.

- Baker, J. A., Dilly, L. J., Aupperlee, J. L., \& Patil, S. A. (2003). The developmental context of school satisfaction: Schools as psychologically healthy environments. School Psychology Quarterly, 18, 206-221.

- Battin-Pearson, S., Newcomb, M.D., Abbott, R.D., Hill, K.G., Catalano, R.F. \& Hawkins, J.D. (2000). Predictors of Early High School Dropout: A Test of Five Theories. Journal of Educational Psychology, Vol. 92, No. 3. 568-582.

- Bergin, C., \& Bergin, D. (2009). Attachment in the Classroom. Educational Psychology Review (21):141-170.

- Birch, S. H., \& Ladd, G. W. (1998). Children's interpersonal behaviors and the teacher-child relationship. Developmental Psychology, 34, 934-946.

- Birch, S., \& Ladd, G. (1997). The teacher-child relationship and children's early school adjustment. Journal of School Psychology, 35(1), 61-79.

- Bowlbi, J. (1958). The Nature of Child's Tie to His Mother. International Journal of Psycho-Analysis, 39, 350373.

- Bowlby, J. (1969). Attachment and Loss. Vol 1. Attachment. New York: Basick Books.

- Bretherton, I. (1985). Attachement theory: Retrospect and prospect. In I. Bretherton \& E. Waters (Eds.) Grownig Points of Attachement Theory and Research. Monographs of the Society for Research on Child Development, 50(1-2) No. 209, 3-38. 
- Bronfenbrenner, U., \& Morris, P. A. (1998). The ecology of developmental processes. In W. Damon \& R. M. Lerner (Eds.), Handbook of child psychology: Vol. 1. Theoretical models of human development (5th ed., pp. 993-1029). New York: Wiley.

- Byrne, B. M. (2001). Structural equation modeling with AMOS: Basic concepts, applications, and programming. New Jersey: Erlbaum.

- Catalano, R. F., Haggerty, K. P., Oesterle, S., Fleming, C. B., \& Hawkins, J. D. (2004). The importance of bonding to school for healthy development: Findings from the Social Development Research Group. Journal of School Health, 74(7), 252-261.

- Connell, J. P. (1990). Context, self, and action: A motivational analysis of self-system processes across the life- span. In D. Cicchetti, \& M. Beeghly (Eds.), The self in transition: From infancy to childhood (pp. 61-97). Chicago, University of Chicago Press.

- Cornelius-White, J. (2007). Learner-centered teacher-student relationships are effective: A meta-

- analysis. Review of Educational Research, 77(1), 113-143.

- Cunningham, N. J. (2007). Level of bonding to school and perception of the school environment by bullies, victims, and bully-victims. The Journal of Early Adolescence, 27(4), 457-478.

- Davis, H. (2003). Conceptualizing the role and influence of student-teacher relationships on children's social and cognitive development. Educational Psychologist, 38(4), 207-234.

- De Ruiter, C., \& Van IJzendoorn, M. H. (1993). Attachment and cognition: A review of the literature. International Journal of Educational Research, 19, 525-540.

- Den Brok, P., Brekelmans, M. \& Wubbels, T. (2006). Multilevel issues in research using students' perceptions of learning environments: The case of the Questionnaire on Teacher Interaction. Learning Environment Research 9:199-213.

- Egeland, B. and Hiester, M. (1995), The Long-Term Consequences of Infant Day-Care and Mother-Infant Attachment. Child Development, 66, (2), 474-485.

- Fisher, D., Fraser, B., \& Cresswell, J. (1995). Using the "Questionnaire on Teacher Interaction" in the Professional Development of Teachers. Australian Journal of Teacher Education, 20 (1), 8-18.

- Goodenow, C. (1993a). The psychological sense of school membership among adolescents: Scale development and educational correlates. Psychology in the Schools, 30, 79-90.

- Goodenow, C. (1993b). Classroom belonging among early adolescent students: Relationships to motivation and achievement. Journal of Early Adolescence, 13, 21-43.

- Goossens, F. \& Van Ijzendoorn, M. (1990). Quality of infants' attachments to professional caregivers: Relation to infant-parent attachment and day-care characteristics. Child Development, 61, 832-837.

- Granot, D., \& Mayseless, O. (2001). Attachment security and adjustment to school in middle childhood. International Journal of Behavioral Development, 25(6), 530-541.

- Greenberg, M. T., Speltz, M. L., \& Deklyen, M. (1993). The role of attachment in the early development of disruptive behavior problems. Development and Psychopathology, 5, 191-213.

- Gurland, S., \& Grolnick, W. (2003). Children's expectancies and perceptions of adults: Effects on rapport. Child Development, 74(4), 1212-1224. 
- Gutman, L.M \& Schoon, I. (2013). The impact of non-cognitive skills on outcomes for young people. Education Endowment Foundation. Retreived August 10, 2015. from https://educationendowmentfoundation.org.uk/ uploads/pdf/Non-cognitive skills literature review 2.pdf

- Hamre, B., \& Pianta, R. (2001). Early teacher-child relationships and the trajectory of children's school outcomes through eighth grade. Child Development, 72(2), 625-638.

- Hamre, B.K., Pianta, R.C., Downer, J.T., DeCoster, J., Mashburn, A.J. Jones, S.M., Brown, J.L., Cappella, E., Atkins, M., Rivers, S.E., Brackett, M.A., \& Hamagami, A. (2013). Teaching through Interactions: Testing a Developmental Framework of Teacher Effectiveness in over 4,000 Classrooms. The Elementary School Journal, Vol. 113, No. 4, 461-487.

- Hattie, J. (2009) Visible learning: a synthesis of meta-analyses relating to achievement. Routledge, NY.

- Hawkins, J. D., Guo, J., Hill, K. G., Battin-Pearson, S., \& Abbott, R. D. (2001). Long-term effects of the social development intervention on school bonding trajectories. Applied Developmental Science, 5(4), 225-236.

- Howes, C., \& Hamilton, C. E. (1992a). Children's relationships with caregivers: Mothers and child care teachers. Child Development, 63, 859-866.

- Howes, C., \& Hamilton, C. E. (1992b). Children's relationships with child care teachers: Stability and concordance with parental attachments. Child Development, 63, 867-878.

- Howes, C., \& Matheson, C. C. (1992). Contextual constraints on the concordance of mother-child and teacher-child relationships. New Directions far Child Development, 57, 25-40.

- Howes, C., \& Ritchie, S. (1999). Attachment organizations in children with difficult life circumstances. Development and Psychopathology, 11, 251-268.

- Howes, C., \& Smith, E. (1995). Relations among child care quality, teacher behavior, children's play activities, emotional security, and cognitive activity in child care. Early Childhood Research Quarterly, 10, 381-404.

- Howes, C., Hamilton, C. E., \& Matheson, C. C. (1994). Children's relationships with peers: Differential associations with aspects of the teacher-child relationship. Child Development, 65, 253-263.

- Howes, C., Phillipsen, L.C., \& Peisner-Feinberg, E. (2000). The consistency of perceived teacher-child relationships between preschool and kindergarten. Journal of School Psychology, 38 (2), 113-132.

- Howes, C., Rodning, C., Galluzzo, D. C., \& Myers, L. (1990). Attachment and child care: Relationships with mother and caregiver. In N. Fox \& G. G. Fein (Eds.), Infant day care: The current debate (pp.169-182). Norwood, NJ: Ablex.

- Jacobsen, T., \& Hofmann, V. (1997). Children's attachment representations: Longitudinal relations to school behavior and academic competency in middle childhood and adolescence. Developmental Psychology, 33, 703-710.

- Jacobsen, T., Edelstein, W., \& Hofmann, V. (1994). A longitudinal study of the relation between attachment representations in childhood and cognitive functioning in childhood and adolescence. Developmental Psychology, 30, 112-124.

- Krstic, K. (2012). School learning and student-teacher attachment. Patchwork. Learning diversities, Belgrade, 30.08. - 1.09. 2012. Conference proceedings: full papers, pp. 164-172. http://www2.unine.ch/files/ content/sites/patchworks2012/files/CONFERENCE_PROCEEDINS.pdf 
- Larose, S., Bernier, A., \& Tarabulsy, G. (2005). Attachment state of mind, learning dispositions, and academic performance during the college transition. Developmental Psychology, 41(1), 281-289.

- Lourdusamy, A., \& Swe Khine, M. (2001, December). Self-evaluation of interpersonal behavior and classroom interaction by teacher trainees. Paper presented at The International Education Research Conference, University of Notre Dame, Fremantle Western Australia. Retrieved Maj 25, 2015. from The Australian Association for Research in Education: http://www.aare.edu.au/01pap/atp01465.htm

- Lynch, M., \& Cicchetti, D. (1992). Maltreated children's reports of relatedness to their teachers. New Directions for Child Development, 57, 81-108.

- Main, M., \& Cassidy, J. (1988). Categories of response to reunion with the parent at age six: Predictable from infant attachment classifications and stable over a 1-month period. Developmental Psychology, 24, 415-526.

- Marchant, G. J., Paulson, S. E., \& Rothlisberg, B. A. (2001). Relations of middle school students perceptions of family and school context with academic achievement. Psychology in the Schools, 38(6), 505-519.

- Moss, E. \& St-Laurent, D. (2001) Attachment at School Age and Academic Performance. Developmental Psychology Vol. 37, No. 6, 863-874.

- Muller, C., Katz, S. R., \& Dance, L. J. (1999). Investing in teaching and learning. Dynamics of the teacherstudent relationship from each actor's perspective. Urban Education, 34, 292-337.

- Murdock, T. B. (1999). The social context of risk: Status and motivational predictors of alienation in middle school. Journal of Educational Psychology, 91, 62-75.

- Murray, C. \& Greenberg, M.T. (2000). Children's relationships with teachers and bonds with school: An investigation of patterns and correlates in middle childhood. Journal of School Psychology, 38 (5), 423-445.

- O'Connor, E., \& McCartney, K. (2007). Attachment and cognitive skills: An investigation of mediating mechanisms. Journal of Applied Developmental Psychology, 28, 458-476.

- O’Donnell, J., Hawkins, J. D., \& Abbott, R. D. (1995). Predicting serious delinquency and substance use among aggressive boys. Journal of Consulting and Clinical Psychology, 63(4), 529-537.

- Parish, M. (2000). The nature of the patient's tie to the therapist (Doctoral dissertation, Adelphi University, 1999). Dissertation Abstracts International, 60, 6378-B.

- Parish, M. and Eagle, M.N. (2003). Attachment to the therapist. Psychoanalytic Psychology Vol. 20, No. 2, 271-286.

- Pekrun, R. (2000). A social cognitive, control-value theory of achievement emotions. In J. Heckhausen (Ed.), Motivational psychology of human development. Oxford, UK: Elsevier.

- Pekrun, R. (2005). Progress and open problems in educational emotion research. Learning and Instruction, 15, 497-506.

- Pianta, R. C. (1999). Enhancing relationships between children and teachers. Washington, DC: American Psychological Association.

- Pianta, R. C., \& Harbers, K. (1996). Observing mother and child behavior in a problem-solving situation at school entry: Relations with academic achievement. Journal of School Psychology, 67, 307-322.

- Pianta, R. C., \& Nimetz, S. (1991). Relationship between children and teachers: Associations with classroom and home behavior. Journal of Applied Developmental Psychology, 12, 379-393. 
- Pianta, R.C. The Student Teacher Relationship Scale; Professional Manual. Retreived February 21, 2014. from http://curry.virginia.edu/uploads/resourceLibrary/STRS_Professional_Manual.pdf

- Pianta, R. C., Belsky, J., Vandergrift, N., Houts, R. M., \& Morrison, F. J. (2008). Classroom effects on children's achievement trajectories in elementary school. American Educational Research Journal, 45 (2), 365-397.

- Pianta, R. C., LaParo, K. M., \& Hamre, B. K. (2008). Classroom Assessment Scoring System (CLASS) Manual, Pre-K. Baltimore, MD: Brookes Publishing.

- Pianta, R. C., Nimetz, S. L., \& Bennett, E. (1997). Mother-child relationships, teacher-child relationships, and school outcomes in preschool and kindergarten. Early Childhood Research Quarterly, 12, 263-280.

- Pianta, R. C., Steinberg, M. S., \& Rollins, K. (1995). The first two years of school: Teacher-child relationships and deflections in children's classroom adjustment. Development \& Psychopathology, 7, 295-312.

- Pianta, R. C., Steinberg, M. S., \& Rollins, K. B. (1995). The first two years of school: teacher-child relationships and deflections in children's classroom adjustment. Development and Psychopathology, 7, 295-312.

- Pianta, R.C. \& La Paro, K. (2003). Improving early school success. Educational Leadership, April, 24-29.

- Popović Ćitić, B. (2012). Vezanost za školu kod učenika koji imaju različite uloge u vršnjačkom nasilju. Specijalna edukacija i rehabilitacija, vol. 11, br. 4. 547-564.

- Radišić, J. \& Baucal, A. (2012). Understanding practice of mathematics and language teachers from their own perspective, paper presented at the 25th International Congress for School Effectiveness and Improvement, Malmo 5th-8th January 2012. http://www.icsei.net/fileadmin/ICSEI/icsei_2012/papers/1791918_ABS.pdf

- Reddy, R., Rhodes, J. E., \& Mulhall, P. (2003). The influence of teacher support on student adjustment in the middle school years: A latent growth curve study. Development and Psychopathology, 15, 119-138.

- Rudasill, K.M \& Rimm-Kaufman, S.E. (2009) Teacher-child relationship quality: The roles of child temperament and teacher-child interactions. Early Childhood Research Quarterly (24), 107-120.

- Rychen, D.S. \& Salganik, L.H. (2003). Key Competencies for a Successful Life and Well-Functioning Society. Hogrefe \& Huber, USA.

- Sakiz, G., Pape, S.J., \& Woolfolk Hoy, A. (2012) Does perceived teacher affective support matter for middle school students in mathematics classrooms? Journal of School Psychology 50 (2012) 235-255.

- Simons-Morton, B. G, Crump, A. D., Haynie, D. L., \& Saylor, K. E. (1999). Student-school bonding and adolescent problem behavior. Health Education Research, 14(1), 99-107.

- Spieker, S. J., Nelson, D. C., Petras, A., Jolley, A., \& Barnard, C. (2003). Joint influence of child care and infant attachment security for cognitive and language outcomes of low-income toddlers. Infant Behavior \& Development, 26, 326-344.

- Stievenart, M., Roskam, I., Meunier, J.C., \& van de Moortele, G. (2011) The reciprocal relation between children's attachment representations and their cognitive ability. International Journal of Behavioral Development 35(1) 58-66.

- Stipek, D., Salmon, J. M., Givvin, K. B., Kazemi, E., Saxe, G., \& MacGyvers, V. L. (1998). The value (and convergence) of practices suggested by motivation research and promoted by mathematics education reformers. Journal for Research in Mathematics Education, 29, 465-488.

- Teo, A., Carlson, E., Mathieu, P., Egeland, B., \& Sroufe, L.A. (1996). A prospective longitudinal study of psychosocial predictors of achievement. Journal of School Psychology, 34, 285-306. 
- Thompson, R. (2008). Early Attachment and Later Development: familiar questions, new answers; In J. Cassidy \& P. Shaver (Eds.). Handbook of Attachment: Theory, Research and Clinical Aplication, (pp. 348-365). New York: The Guilford Press.

- Tucker, C. M., Zayco, R. A., Herman, K. C., Reinke, W. M., Trujillo, M., Carraway, K., et al. (2002). Teacher and child variables as predictors of academic engagement among low-income African American children. Psychology in the Schools, 39, 477-488.

- Valiente, C., Lemery-Chalfant, K., Swanson, J., \& Reiser, M. (2008). Prediction of children's academic competence from their effortful control, relationships, and classroom participation. Journal of Educational Psychology, 100, 67-77.

- Van IJzendoorn, M. H., \& Vliet-Visser, S. (1988). The relationship between quality of attachment in infancy and IQ in kindergarten. Journal of Genetic Psychology, 149, 23-28.

- Van IJzendoorn, M. H., Sagi, A., \& Lambermon, M. W. E. (1992). The multiple caretaker paradox: Data from Holland and Israel. In R. C. Pianta (Ed.), Beyond the parent: The role of other adults in children's lives. New directions for child development, Vol. 57 (pp. 5-24). San Francisco: Jossey-Bass.

- Van IJzendoorn, M., Dijkstra, J., \& Bus, A. (1995). Attachment, intelligence, and language: A meta-analysis. Social Development, 4, 115-128.

- Videnović, M. \& Radišić, J. (2011). Anksioznost u vezi sa učenjem matematike: Matematika - bauk ili ne? Psihološka istraživanja, Vol. 14. str.157-177.

- Walberg, H.J. (1981). A psychological theory of educational productivity. In F. Farley \& N.J. Gordon (Eds.), Psychology and education: the state of the union (pp. 81-108). Berkeley, CA: McCutchan.

- Weinfield, N. S., Sroufe, A., Egeland, B., \& Carlson, E. (1999). The nature of individual differences in infantcaregiver attachment. In J. Cassidy \& P. Shaver (Eds.), Handbook of attachment: Theory, research, and clinical applications (pp. 68-88). New York: Guilford.

- Weinfield, N. S., Sroufe, L. A., Egeland, B., \& Carlson, E. (2008). Individual differences in infant-caregiver attachment: conceptual and empirical aspects of security. In J. Cassidy \& P. R. Shaver (Eds.), Handbook of attachment: Theory, Research and Clinical Application (2nd ed.). (pp. 78-101) New York: Guilford.

- Wentzel, K. R. (1997). Student motivation in middle school: The role of perceived pedagogical caring. Journal of Educational Psychology, 89(3), 411-419.

- Wubbels, T. \& Brekelmans, M. (2005) Two decades of research on teacher-student relationships in class. International Journal of Educational Research (43), 6-24.

- Wubbels, Th., \& Levy, J. (1991). A comparison of interpersonal behavior of Dutch and American teachers. International Journal of Intercultural Relations, 15, 1-18.

- Wubbels, Th., \& Levy, J. (Eds.). (1993). Do you know what you look like: Interpersonal relationships in education. London, England: Falmer Press.

- Wubbels, Th., Creton, H. A., \& Hooymayers, H. E (1992). Review of research on teacher communication styles with use of the Leary model. Journal of Classroom Interaction, 27, 1-12.

- Zeidner, M. (1998). Test anxiety. The state of the art. New York: Plenum.

- TIMSS (2011). TIMSS and PIRLS 2011: Relationships Among Reading, Mathematics and Science Achievement at the Fourth Grade - Implications for Early Learning. Retrieved Octobar 6., 2014. from http://timss. 
bc.edu/timsspirls2011/downlouds/TP11 Relationship Report.pdf \& Instruction to Engage Students in Learning Scale. Retrieved Octobar 6., 2014. from http://timss.bc.edu/methods/pdf/T11_G4 G_Scales IES. pdf

- PISA (2012). Technical Report. Retrieved Octobar 6., 2014. from http://www.oecd.org/pisa/pisaproducts/ PISA-2012-techinical-report-final.pdf

\section{др Ксенија Крстић}

Одељење за психологију, Филозофски факултет, Универзитет у Београду, Србија

\section{Везаност ученика и наставника као фактор школског постигнућа}

Традиционална струја истраживања у психологији образовања фокусирана је на изучавање когнитивних аспеката учења, наставе и интеракције ученика и наставника. Све већи број истраживања указује да су социоемоционално добростање ученика у школи и квалитет интеракције ученик-наставник суштински значајни за прилагођавање школи, учење и школско постигнуће. У овом раду бавимо се значајем социоемоционалног односа ученика и наставника из перспективе теорије везивања. Основна идеја овог истраживања јесте да везаност ученика за наставника, као основа њихове социоемоционалне интеракције, може поспешити учење и развој.

Велики број истраживања је показао да подржавајућа и топла интеракција са наставником може имати утицај на учење, социјалне компетенције и прилагођавање школи. Наставник може бити „сигурна база“ за истраживање и учење у школи, пружајући исту емоционалну сигурност и подршку које карактеришу и сензитивно и респонзивно родитељство. Студије су показале да сигурна везаност за родитеље има значајне импликације за развој когнитивних способности, бољу школску прилагођеност, виша школска постигнућа, развијеније социјалне компетенције. На сличан начин и сигурна везаност за наставника повезана је са вишим школским постигнућем, позитивнијим ставовима према школи, већим залагањем и учешћем у активностима на часу и ређим понављањем разреда.

У истраживањима о улози емоција у образовању доминирају истраживања која су фокусирана на значај појединих емоција (на пример, испитна анксиозност) или на ученичке или наставничке емоције и њихову функцију и утицај на когнитивне процесе, наставу и учење. Истраживања која се баве интеракцијом најчешће испитују педагошку интеракцију наставника и ученика и начине на које ученици стичу знања и вештине током те интеракције. Нову струју истраживања у образовању чине студије које се баве микроанализом процеса интеракције и специфичним поступцима ученика и наставника. Оно што недостаје су истраживања фокусирана на емоционални однос и интеракцију ученика и наставника. Тај емоционални однос је релативно стабилан и трајан фактор који утиче не само на динамику односа и интеракција ученика и наставника већ и на процес наставе и учења.

Основни циљ овог истраживања јесте да утврди како су емоционални квалитет интеракције наставника и ученика, специфични однос везаности и карактеристике наставничке праксе повезани са два важна образовна исхода: школским успехом и позитивним односом ученика према школи и учењу. 
Рад је усмерен на истраживање ученичке интеракције и везаности за учитељицу на крајучетвртог, односно наставника математике на крају седмог разреда основне школе. Истраживањем је обухваћено триста шездесет шест ученика из пет београдских основних школа. За потребе овог истраживања упитник је конструисан адаптацијом неколико постојећих скала којима се мере различите димензије односа ученик-наставник. Упитником су обухваћене следеће димензије: димензије социоемоционалног односа наставника и ученика - тражење близине, посебност, протест због одвајања, уточиште, сигурна база (димензије везаности), отворена комуникација и блискост; димензије наставничке праксе педагошка подршка, вођство, захтевност, помоћ/ пријатељски однос, задовољство, конфликтност. Као меру образовног постигнућа узели смо ученички позитиван однос према школи и учењу и оцене из српског језика, математике и просечну оцену на крају претходног разреда.

Анализа поузданости скала показала је да две скале (захтевност и вођство) имају ниску поузданост, због чега су искључене из даљих анализа. Факторском анализом утврђено је да се димензије социоемоционалног односа групишу око једног фактора који је назван везаност за наставника. Димензије наставничке праксе: помоћ/ пријатељски однос, задовољство и конфликтност такође чине један фактор, назван позитиван емоционални однос према ученицима. Ове димензије, уз димензије педагошка подршка и позитиван однос према школи и учењу, и школске оцене биле су основа за SEM анализу (structural equation modeling) на подузорцима ученика четвртог и седмог разреда.

У теоријском моделу претпостављено је да везаност за наставника утиче на школске оцене и позитиван однос према школи и учењу, а да наставничка педагошка подршка и позитиван емоционални однос са ученицима утичу на везаност за наставника, али и директно на оба образовна постигнућа. SEM анализом утврђено је да, на оба узраста, теоријски модел одговара емпиријски добијеним подацима, али и да постоје везе међу варијаблама/димензијама које нису значајне.

На узорку ученика четвртог разреда утврђено је да везаност за учитељицу утиче и на позитиван однос према школи и учењу и на школске оцене. С друге стране, везаност за учитељицу зависи од обе димензије наставничке праксе - од педагошке подршке и позитивног емоционалног односа према ученицима. Истовремено, педагошка подршка утиче и директно на школске оцене, док позитиван емоционални однос са ученицима утиче на њихов општи однос према школи и учењу. Осим тога, ове две димензије наставничке праксе су повезане, што значи да ученици опажају да учитељица која има позитивнији емоционални однос са њима даје и квалитетнију педагошку подршку.

На узрасту ученика седмог разреда везаност за наставника математике утиче само на позитиван однос ученика према школи и учењу, али не и на оцене из математике. Везаност за наставника математике зависи само од наставничког позитивног емоционалног односа према ученицима, не и од квалитета педагошке подршке коју пружа. На оцене из математике утичу и квалитет педагошке подршке коју наставник пружа, али и позитиван емоционални однос према ученицима. Осим тога, на овом узрасту нема међусобне везе између ове две димензије наставничке праксе.

На основу ових резултата, може се закључити да на оба узраста постоји везаност ученика за учитељицу, односно наставника математике и да та везаност утиче на један од образовних исхода, позитиван однос према школи и учењу. На млађем узрасту учитељица је важна као фигура везаности и топао, сигуран, подржавајући однос са учитељицом повољно утиче и на школско постигнуће мерено оценама ученика. Ученици ће развити сигурну везаност за учитељицу која има позитиван емоционални однос са ученицима, што значи да је пријатељски расположена, помаже им, задовољна је својим ученицима и ретко је са њима у сукобу; и истовремено пружа квалитетну педагошку подршку 
и фидбек. На старијем узрасту, везаност за наставника математике имаће утицај само на генерални позитиван однос према школи и учењу. На овом узрасту ученици имају мање потреба, али, имајући у виду да се ради о предметном наставнику, и мање прилика да развију однос везаности са једним предметним наставником. Оно што одређује њихов успех из математике, су позитиван емоционални однос наставника и квалитет педагошке подршке.

Утицај везаности за наставника на образовне исходе, утврђен у овом истраживању, указује на значај успостављања позитивног емоционалног односа у учионици и развијања топлог, сензитивног и подржавајућег окружења за учење у школи.

Кључне речи: везаност за наставника, педагошка подршка, емоционални однос, образовна постигнућа. 